\title{
Peningkatan Fungsi Transformatif Khotbah Jumat di Masjid-Masjid Srihardono Pundong Bantul
}

\author{
Marsudi $^{1}$, Yunahar llyas ${ }^{2}$ \\ 1. Prodi Pendidikan Agama Islam UMY, Kampus Terpadu UMY Jln Brawijaya Kasihan Bantul \\ 2 Program Doktor Psikologi Pendidikan Islam, Kampus Terpadu UMY JIn Brawijaya Kasihan Bantul \\ Email: marsudi@umy.ac.id. \\ DOI : 10.18196/ppm.31.151
}

\begin{abstract}
Abstrak
Khotbah Jumat di masjid-masjid wilayah Pundong Bantul, dilakukan sekedar sebagai ritual rutin penggugur kewajiban. Fungsi yang ditonjolkan adalah fungsi normative 'ubudiyyah, bukan fungsi transformatifnya. Ditemukan beberapa masalah, yaitu rendahnya kompetensi profesional dan pedagogik para khatib, persebaran khatib yang kurang merata serta bacaan al-Qur'an dan Hadits para khatib dan imam belum fasih dan benar. Persoalan-persoalan tersebut dipecahkan dengan menyelenggarakan pelatihan intensif khatib dan imam salat, studi lapangan di masjid-masjid ideal serta penjadwalan khatib terpadu dengan aplikasi berbasis Microsoft Excel. Hasil pelatihan menunjukkan adanya peningkatan kompetensi profesional dan pedagogik khatib yang cukup signifikan dari skor rata-rata sebesar 65,9 (Pretest) menjadi 79,3 (Posttest). Para khatib menjadi lebih paham tentang figh, adab-adab dan retorika khotbah.Terkait kualitas bacaan al-Quran, pelatihan berhasil menumbuhkan kesadaran para khatib akan kemampuan diri mereka dalam membaca al-Qur'an dan Hadits yang masih di bawah standar. Para khatib menyepakati untuk membuat kegiatan belajar membaca al-Qur'an dan Hadits bersama sebagai tindak lanjut pelatihan. Adapun kegiatan penjadwalan khatib terpadu yang dilakukan oleh Bagian Tabligh dan Kemasjidan Pimpinan Ranting Muhammadiyah Srihardono Pundong dengan menggunakan aplikasi berbasis Microsoft Excel berhasil mengatasi kurangnya personel khatib di masjid-masjid tertentu.

Kata Kunci: Khotbah Jumat, Khatib, Imam Salat
\end{abstract}

\section{Pendahuluan}

Salah satu ibadah wajib yang harus dilakukan oleh seorang muslim adalah ibadah Jumat. Rangkaian ibadah ini terdiri dari khotbah dan salat dua rakaat. Salah satu rukun khotbah adalah wasiat taqwa dari khatib untuk seluruh jamaah dan khatib sendiri. Taqwa menurut Ar-Raghib Al-Asfahani adalah menjaga jiwa dari perbuatan yang membuatnya berdosa, dengan meninggalkan apa yang dilarang. Taqwa menjadi sempurna dengan meninggalkan sebagian yang dihalalkan (Al-Mufradat fi Gharibi al-Qur`an: 531). Imam Muhyidin Yahya Bin Syarif AnNawawi, mendenifisikan taqwa dengan "Mentaati perintah dan laranganNya. Maksudnya menjaga diri dari kemurkaan dan adzab Allah" (Tahriru Alfadzi At-Tanbih: 322). Sementara itu, Imam Ali Bin Muhammad Al-Jurjani, berpendapat bahwa taqwa adalah menjaga diri dari siksa Allah dengan menta'atiNya (Mu'jamu at-Ta'rifat: 68). Karakter muttaqin (orang yang bertaqwa) mencakup dua dimensi; dimensi hablun min Allah (vertical transcendent) dan hablun min annaas (horizontal intransendent). Dengan demikian, muttaqin merupakan tipe manusia yang ideal. Dia memiliki interaksi yang baik dengan Tuhannya, serta berinteraksi sosial secara ideal dengan lingkungannya, baik lingkungan manusia maupun alam semesta (biotik dan abiotik). Muttaqin adalah agen-agen amal salih di masyarakat, para penggerak pembangunan, agen-agen perubahan dan pencerahan serta selalu memberi solusi terhadap segala problem kemasyarakatan.

Mencermati pada capaian atau target dari khotbah Jumat, yaitu terbentuknya insan yang taqwa, maka khotbah Jumat dengan demikian memiliki peran strategis bagi terciptanya sebuah masyarakat yang adil makmur sejahtera (baldatun thoyyibatun wa Rabbun ghofur). Deskripsi di atas merupakan kondisi ideal dari peran khotbah Jumat. Pada tataran praksisnya di masyarakat Islam Indonesia khotbah Jumat cenderung masih diperlakukan sebagai sekedar sebuah ritual rutin yang harus dilakukan untuk menggugurkan sebuah kewajiban saja. Fungsi yang ditonjolkan adalah fungsi normative 'ubudiyyah saja, bukan fungsi transformatifnya.

Pada khotbah Jumat di beberapa masjid di Srihardono Pundong Bantul, ditemukan realitas betapa kurang efektifnya pesan-pesan yang disampaikan oleh khatib kepada para jamaah. Keefektifan khotbah Jumat masih rendah disebabkan rendahnya kompetensi profesional dan pedagogik para khatib. Diketahui juga bahwa bacaan Al-Qur’an dan Hadits para khatib dan 
imam yang belum fasih dan benar sesuai kaidah-kaidah ilmu tajwid. Selain itu, jumlah personel khatib yang masih kurang di beberapa tempat sedangkan di tempat lain ada para khatib yang cukup berkompeten tetapi belum dimanfaatkan.

Tiga persoalan di atas, diatasi dengan beberapa solusi: Focus Group Discussion, pelatihan intensif khatib dan imam, studi lapangan di masjid-masjid ideal dan penjadwalan terpadu khatib dengan aplikasi berbasis Microsoft Excel.

\section{Metode Pelaksanaan}

Pengabdian masyarakat ini dilaksanakan dengan cara berikut:

1. Penilaian awal (initial assessment) permasalahan.

Identifikasi masalah secara mendetail dan komprehensif dilakukan dalam sebuah forum Focus Group Discussion (FGD) yang dihadiri oleh tim pengabdian pada masyarakat dari UMY, pengurus harian PRM Srihardono, anggota Bagian Tabligh dan Kemasjidan PRM Srihardono dan perwakilan dari masing-masing takmir masjid binaan PRM Sihardono. Output dari kegiatan ini adalah tumbuhnya kesadaran bahwa khotbah Jumat yang selama ini dilakukan belum berdaya dalam membangun karakter taqwa para jamaah.

2. Peningkatan pengetahuan dan kesadaran khatib.

Kegiatan yang dilakukan adalah pelatihan khatib dan imam salat. Pelatihan diikuti 43 khatib dan calon khatib di masjid-masjid binaan PRM Srihardono. Output pelatihan ini adalah meningkatnya kesadaran akan urgensi khotbah Jumat dalam dakwah Islam untuk membentuk karakter taqwa para jamaah. Para khatib tercerahkan sehingga tidak memperlakukan hutbah Jumat hanya sekedar kewajiban ritual mengesampingkan fungsi transformatifnya. Pelatihan ini juga berhasil meningkatkan kompetensi profesional dan pedagogik mereka dalam menyampaikan khotbah. Pelatihan diawali dengan pretest, penyampaian materi tentang fiqh dan retorika khotbah dilanjutkan praktik khotbah oleh peserta serta bedah kasus fiqhiyyah. Materi kedua adalah Tahsinul Qur 'an. Pelatihan diakhiri dengan Rencana Tindak Lanjut (RTL) dan posttest. Dilakukan juga studi lapangan di masjid-masjid yang dipandang ideal.

3. Pembenahan Jadwal Khatib dengan Aplikasi Berbasis Microsoft Excel.

Pembenahan jadwal khatib yang terpusat dilakukan oleh pengurus Bagian Tabligh dan Kemasjidan PRM Srihardono didampingi oleh tim pengabdian dari UMY dengan menggunakan aplikasi berbasis Microsoft Excel yang dibuat oleh website https://projects.co.id/.

\section{Hasil dan Pembahasan}

1. Penilaian awal (initial assessment) permasalahan.

Kegiatan pengabdian masyarakat diawali dengan identifikasi masalah secara mendetail dan komprehensif dalam sebuah forum Focus Group Discussion (FGD). Kegiatan yang diselenggarakan di rumah Bapak Badri ini dihadiri oleh tim pengabdian pada masyarakat dari UMY, pengurus PRM Srihardono, anggota Bagian Tabligh dan Kemasjidan PRM Srihardono dan perwakilan dari masing-masing takmir masjid binaan PRM Sihardono. Hasil dari FGD ini adalah tumbuhnya kesadaran bahwa khotbah Jumat yang selama ini dilakukan di masjid-masjid wilayah Srihardono belum berdaya dalam membangun karakter taqwa para jamaah.

Kegiatan ini juga menghasilkan rumusan-rumusan kongkrit permasalahan di sekitar 
ibadah Jumat yang melandasi pentingnya segera dicarikan solusi pemecahannya berupa pelatihan khotbah untuk para khatib dan imam. Permasalahan pertama adalah masih rendahnya kompetensi profesional berupa wawasan fiqh dan adab-adab khotbah serta kompetensi pedagogis yang tampak pada belum diterapkannya secara baik ilmu retorika khotbah oleh para khatib. Permasalahan kedua adalah belum standarnya kemampuan khatib dan imam dalam membaca Al-Quran sesuai dengan kaidah ilmu tajwid. Adapun permasalahan ketiga adalah kurang meratanya domisili para khatib. Terdapat dusun-dusun yang surplus khatib, sementara di dusun-dusun lainnya kekurangan khatib. Forum ini juga berhasil membentuk kepanitiaan kegiatan pelatihan, pembiayaan, peserta, tempat dan waktu pelatihan. Adapun untuk desain pelatihan diserahkan sepenuhnya kepada tim pengabdian dari UMY.

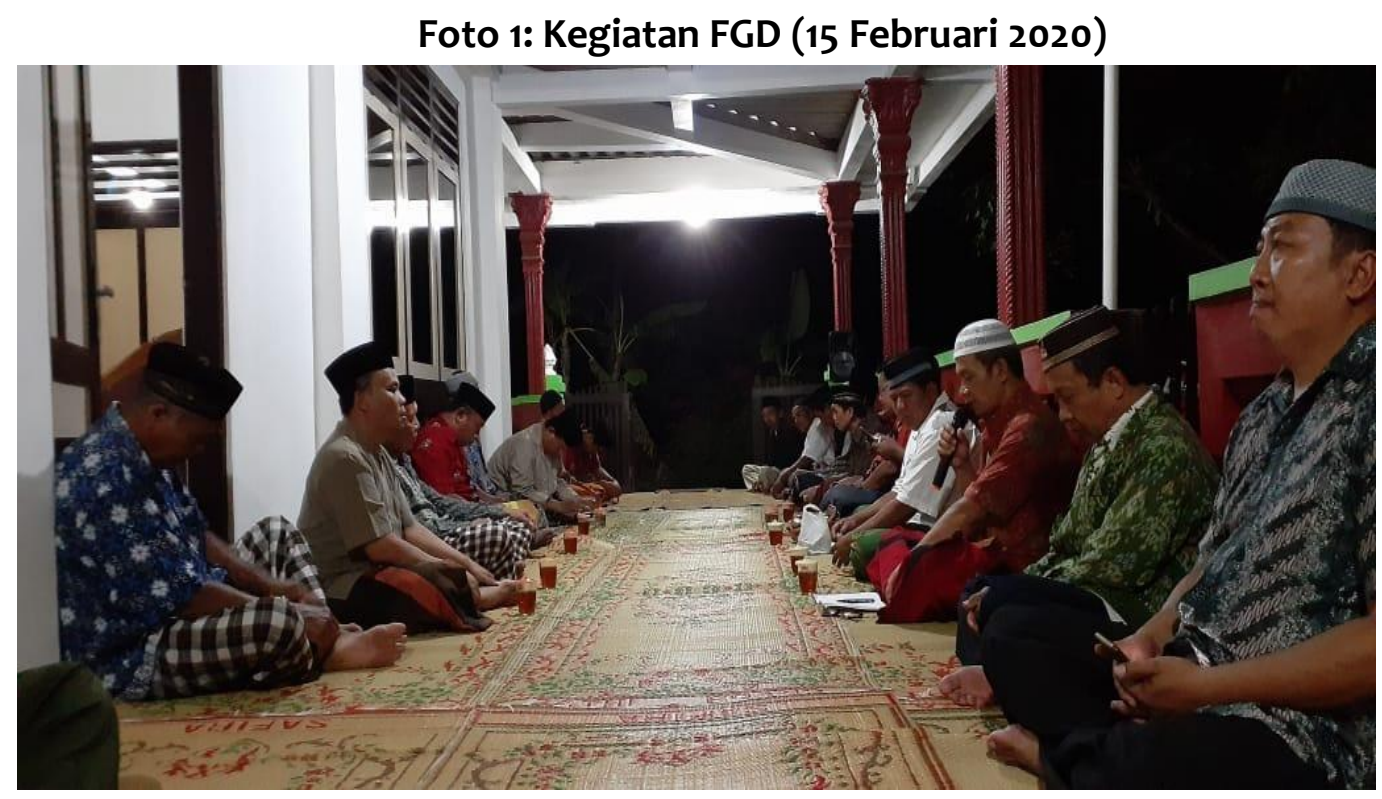

2. Pelatihan Khatib dan Imam.

Pelatihan ini semula direncanakan pada tanggal 25 Maret 2020. Disebabkan adanya pandemi Covid-19 maka pelaksanaannya diundur pada Ahad, 9 Agustus 2020. Pelatihan diselenggarakan di Rumah Makan Yu Sum yang berada di sekitar kawasan wisata Dlingo Bantul. Kegiatan ini diikuti oleh 41 orang khatib dan imam perwakilan dari masjid-masjid binaan Muhammadiyah di wilayah Srihardono, Panjangrejo, dan Seloharjo Pundong Bantul.

Pelatihan dimulai dengan pretest. Soal pretest dibuat dengan menggunakan platform Google Formulir. Adapun bentuk soalnya adalah objektif test model multiple choice dengan 4 alternatif jawaban (a,b,c dan d). Jumlah soal adalah 25. Setiap jawaban yang benar diberi bobot 4 sedang yang salah adalah 0 . Materi yang ditanyakan terdiri dari tiga bagian. Bagian pertama adalah tentang fiqh khotbah Jumat. Bagian kedua adalah adab-adab khotbah Jumat. Sedangkan bagian ketiga tentang retorika khotbah. Dari 41 peserta, terdapat 38 peserta yang mengirimkan jawaban. Setelah dilakukan pencermatan, yang layak untuk dianalisis adalah 36 jawaban. Diperoleh rata-rata skor sebesar 65,9. Daftar perolehan nilai pretest disajikan dalam tabel 1.

Kegiatan pelatihan dilanjutkan dengan acara seremonial berupa pembukaan pelatihan oleh ketua Bagian Tabligh dan Kemasjidan Pimpinan Ranting Muhammadiyah Srihardono, Bapak Ahmad Sholihin. Adapun materi pertama adalah tentang fiqh dan adab-adab dalam khotbah Jumat yang disampaikan oleh Drs. H. Nashrudin, M.Si. Pemateri memaparkan fiqh 
khotbah Jumat dalam perspektif Tarjih Muhammadiyah. Menurut Tarjih Muhammadiyah ritual salat Jumat tidak didahului dengan salat sunah rawatib qabliyah. Adzan hanya dilakukan sekali. Khatib tidak perlu lagi membawa tombak. Adapun rukun khotbah adalah memuji Allah dirangkai dengan membaca syahadatain, bersholawat Nabi, wasiyat taqwa, membaca ayat al-Qur`an serta mendoakan kaum muslimin di khotbah kedua. Sesi ini diteruskan dengan tanya jawab antara peserta dengan pemateri.

Adapun materi kedua adalah tentang retorika khotbah Jumat yang disampaikan oleh Drs. H. Marsudi, M.Ag. Pemateri memaparkan kelemahan-kelemahan retorika khatib saat berkhotbah meliputi lemahnya suara, intonasi suara dan ekspresi wajah yang datar, pandangan mata yang hanya tertuju pada teks, bacaan Qur'an dan Hadits yang banyak salah dan kurang peka pada fungsi pengeras suara. Tema khotbah yang disampaikan juga sering tidak relevan dengan kebutuhan jamaah.

Foto 2: Pemateri Fiqh dan Adab-adab Khotbah (Drs. H. Nashrudin, M.Si)

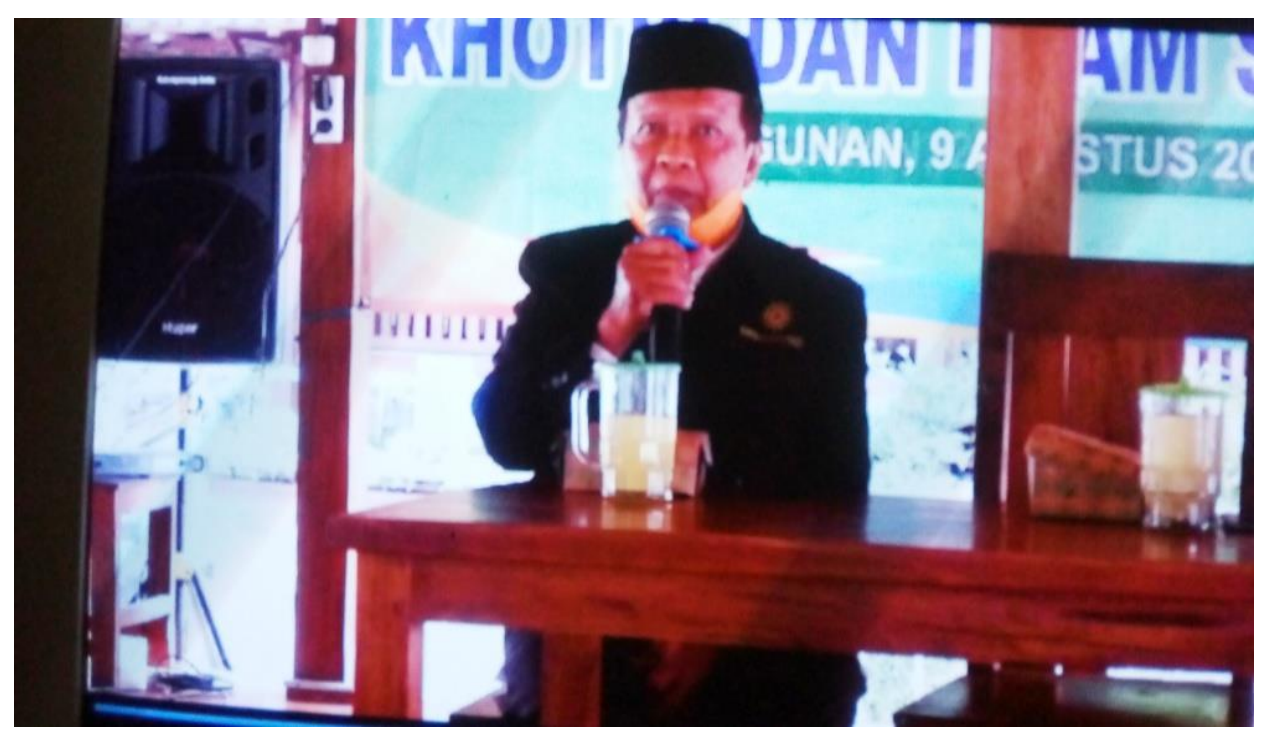

Foto 3: Pemateri Retorika Khotbah (Drs. H. Marsudi, M.Ag) 


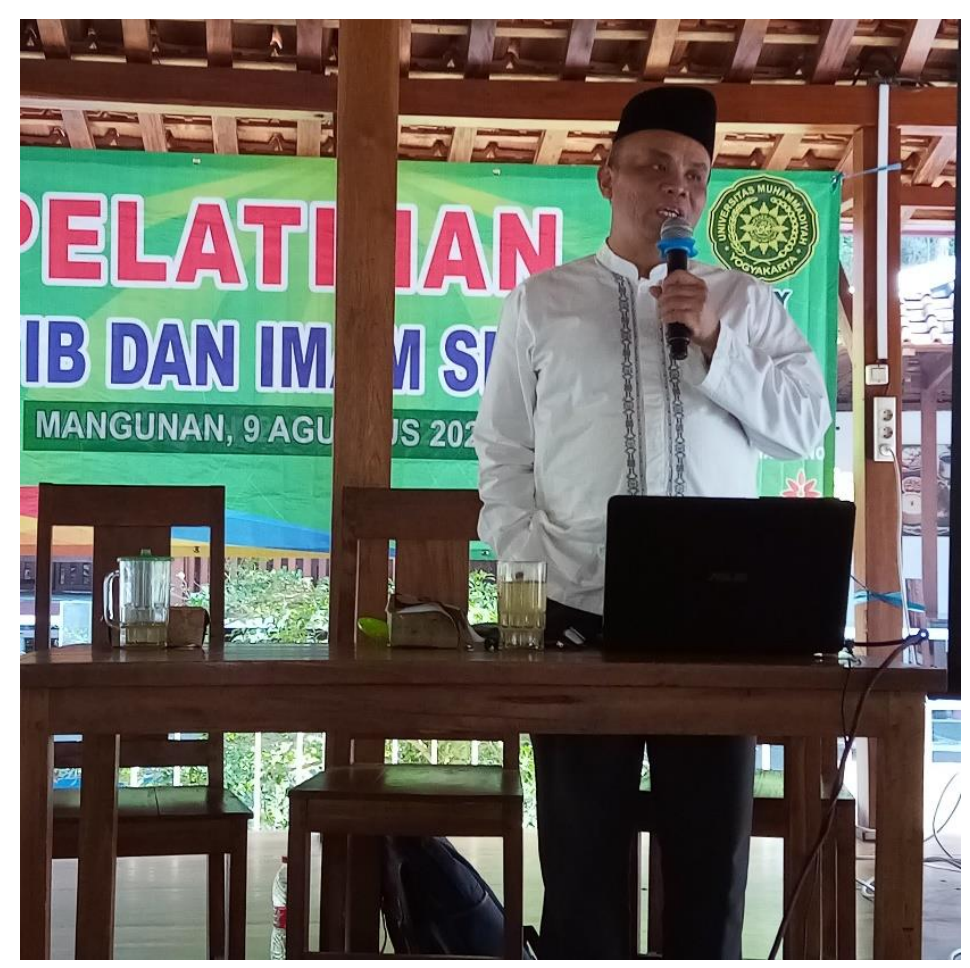

Selanjutnya sesi ketiga berupa praktik khotbah oleh peserta pelatihan. Praktik pertama dilakukan oleh Bapak Ma’ruf Yuniarno. Praktikan kedua adalah Bapak Zainudin. Para peserta diberi kesempatan untuk mengevaluasi dua praktikan tersebut baik dari segi fiqh khotbah maupun segi retorikanya. Dari evaluasi yang dilakukan, tampak bahwa para peserta pelatihan telah menguasai ilmu-ilmu fiqh dan retorika khotbah dengan baik.

\section{Foto 4: Praktikan Khotbah Jumat (Ma'ruf Yuniarno)}

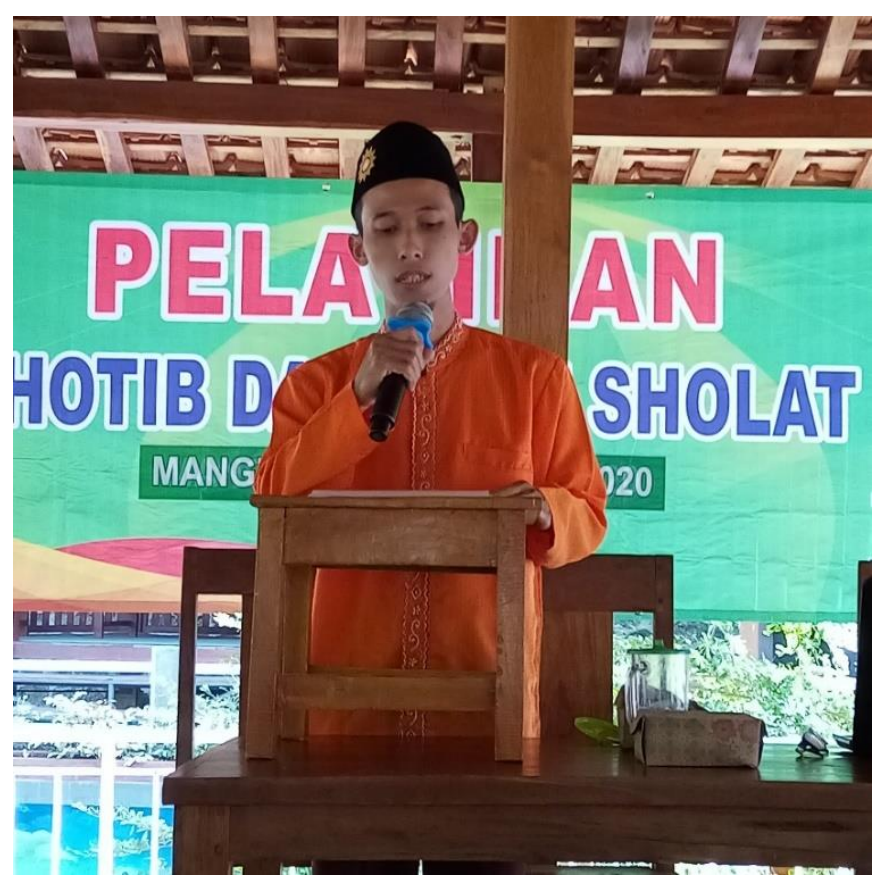

Pada materi terakhir, yaitu tahsin al-Qur`an, Ustadz Endro Suwarno melakukan tes 
langsung kemampuan membaca al-Qur`an masing-masing peserta. Hasil tes menunjukkan bahwa kemampuan baca al-Qur’an para peserta masih secara umum masih di bawah standar. Secara singkat, Endro Suwarno menyampaikan dasar-dasar tahsin al-Qur an. Sesi ini berhasil menyadarkan para peserta bahwa kemampuan membaca al-Qur`an mereka harus ditingkatkan dengan cara mengaji bersama secara rutin pascapelatihan.

\section{Foto 5: Pemateri Tahsin Al-Quran (Ustadz Endro Suwarno)}

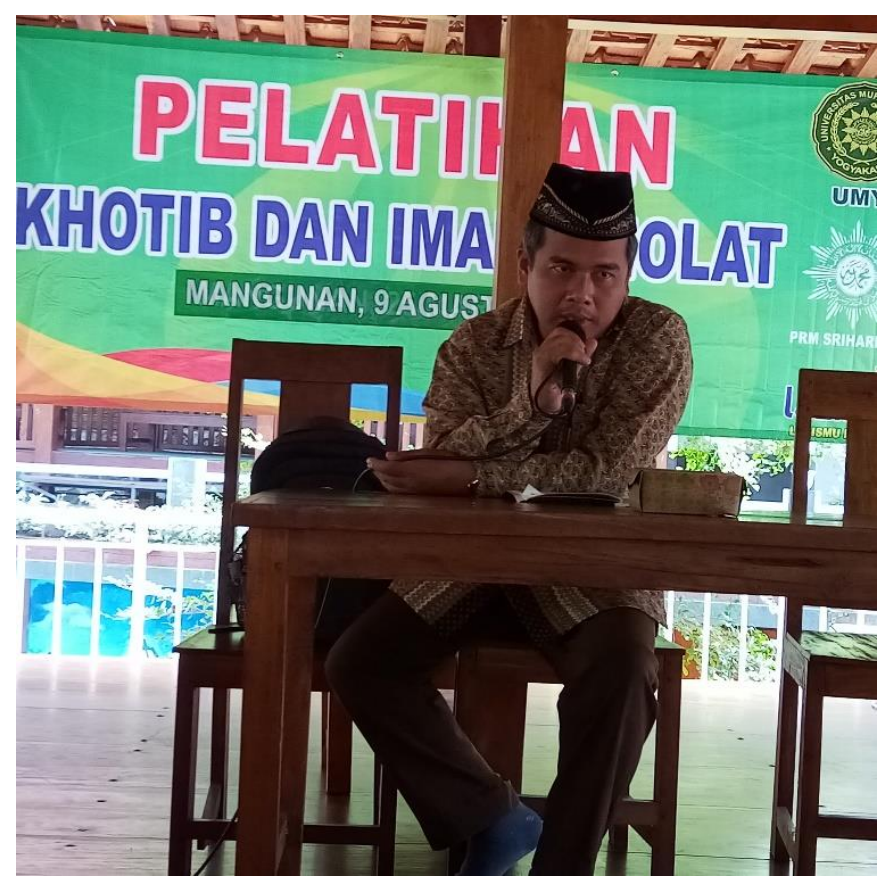

Foto 6: Peserta Pelatihan

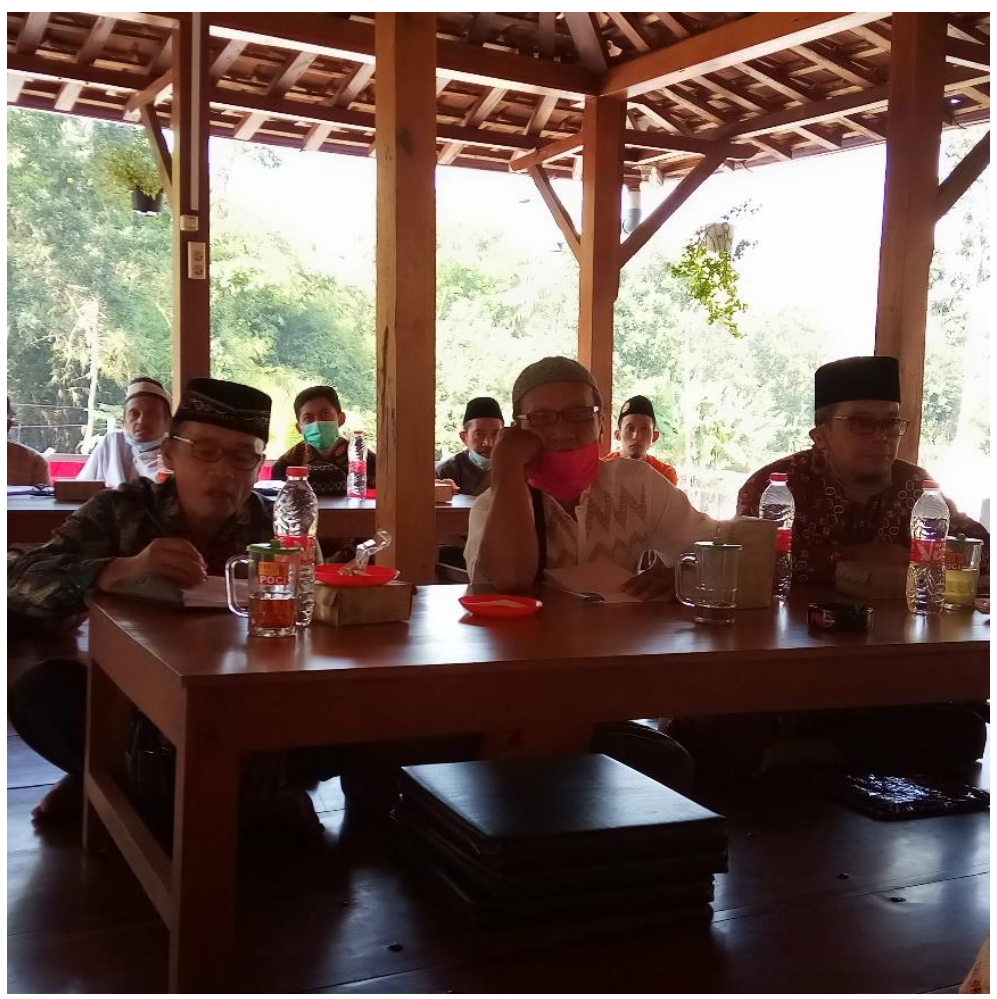


Pelatihan diakhiri dengan posttest. Didapat skor rata-rata posttest sebesar 79,3. Hasil pretest dan posttest disajikan dalam tabel berikut:

Tabel 1: Perbandingan Hasil Pretest dan Posttest

\begin{tabular}{|c|c|c|}
\hline NO PESERTA & NILAI PRE TEST & NILAI POST TEST \\
\hline 1 & 64 & 76 \\
\hline 2 & 72 & 84 \\
\hline 3 & 56 & 72 \\
\hline 4 & 68 & 80 \\
\hline 5 & 76 & 88 \\
\hline 6 & 84 & 92 \\
\hline 7 & 68 & 80 \\
\hline 8 & 72 & 84 \\
\hline 9 & 76 & 88 \\
\hline 10 & 72 & 80 \\
\hline 11 & 80 & 92 \\
\hline 12 & 60 & 76 \\
\hline 13 & 64 & 84 \\
\hline 14 & 64 & 80 \\
\hline 15 & 52 & 72 \\
\hline 16 & 64 & 76 \\
\hline 17 & 56 & 72 \\
\hline 18 & 76 & 88 \\
\hline 19 & 60 & 76 \\
\hline 20 & 52 & 72 \\
\hline 21 & 48 & 68 \\
\hline 22 & 56 & 72 \\
\hline 23 & 64 & 76 \\
\hline 24 & 60 & 76 \\
\hline 25 & 76 & 92 \\
\hline 26 & 80 & 92 \\
\hline 27 & 84 & 92 \\
\hline 28 & 52 & 68 \\
\hline 29 & 64 & 76 \\
\hline 30 & 76 & 84 \\
\hline 31 & 52 & 68 \\
\hline 32 & 60 & 76 \\
\hline 33 & 60 & 72 \\
\hline 34 & 56 & 68 \\
\hline 35 & 72 & 80 \\
\hline 36 & 76 & 84 \\
\hline RATA-RATA & 65.9 & 79.3 \\
\hline
\end{tabular}


Dari tabel di atas tampak adanya peningkatan rata-rata skor sebelum pelatihan $(65,9)$ menjadi 79,3 sesudah mengikuti pelatihan. Adanya peningkatan skor yang cukup signifikan tersebut disimpulkan bahwa pelatihan yang diselenggarakan cukup efektif dalam meningkatkan kompetensi profesional dan pedagogik khatib dan imam.

3. Penyusunan Jadwal Terpadu Khatib Jumat

Program ini telah dilaksanakan oleh Bagian Tabligh dan Kemasjidan PRM Srihardono dibimbing oleh tim pengabdian UMY. Penjadwalan terpadu memanfaatkan aplikasi berbasis Microsoft Excel yang dibeli dari website https://projects.co.id. Dengan adanya jadwal terpadu ini tidak ada lagi masjid-masjid yang kekurangan khatib ibadah Jumat.

\section{Simpulan}

1. Kegiatan pengabdian masyarakat yang telah terlaksana dalam rangka pemecahan masalah belum efektifnya khotbah Jumat di masjid-masjid wilayah Srihardono Pundong adalah Focus Group Discussion (FGD) untuk mengidentifikasi permasalahan di sekitar khotbah, Pelatihan khatib dan imam dengan materi Fiqh dan Adab-adab khotbah, Retorika Khotbah, Praktik Khotbah, dan Tahsin Al-Quran.

2. Hasil pelatihan menunjukkan adanya peningkatan kompetensi profesional dan pedagogik khatib yang cukup signifikan dari skor rata-rata sebesar 65,9 (Pretest) menjadi 79,3 (Posttest). Para khatib menjadi lebih paham tentang fiqh, adab-adab, dan retorika khotbah. Terkait kualitas bacaan al-Quran, pelatihan berhasil menumbuhkan kesadaran para khatib akan kemampuan diri mereka dalam membaca al-Qur’an dan Hadits yang masih di bawah standar. Para khatib menyepakati untuk membuat kegiatan belajar membaca al-Qur`an dan Hadits bersama sebagai tindak lanjut pelatihan. Adapun kegiatan penjadwalan khatib terpadu yang dilakukan oleh Bagian Tabligh dan Kemasjidan Pimpinan Ranting Muhammadiyah Srihardono Pundong dengan menggunakan aplikasi berbasis Microsoft Excel berhasil mengatasi kurangnya personel khatib di masjid-masjid tertentu.

\section{Ucapan Terima Kasih}

Ucapan terimakasih disampaikan kepada:

1. LP3M Universitas Muhammadiyah Yogyakarta atas kontrak penugasan program pengabdian masyarakat tahun 2019/2020.

2. Pimpinan Ranting Muhammadiyah Srihardono Pundong.

3. Para pemateri dan peserta pelatihan.

\section{Daftar Pustaka}

Ali Bin Muhammad Al-Jurjani, Mu'jamu at-Ta'rifat, Kairo, Dar al-Fadhilah, t.t.

Ar-Raghib Al-Asfahani, Al-Mufradat fi Gharibi al-Qur`an, Maktabah Nazar Musthofa Al-Baz,

t.t.

https://projects.co.id/

M. Tahir, Khotbah Jumat di Kota Samarinda (Analisis Kesiapan Para Khatib di Kota Samarinda), Jurnal FENOMENA, Volume V, No. 2, 2013.

Muhyidin Yahya Bin Syarif An-Nawawi, Tahriru Alfadzi At-Tanbih, Yayasan Resala, 1417 H. Yunahar Ilyas, Kuliah Aqidah, 2016, Yogyakarta, LPPI UMY 